\title{
Terpenoids of the Heartwood of Chamaecyparis Nootkatensis
}

\author{
M. A. Khasawneh ${ }^{1, *}$, J. J. Karchesy ${ }^{2}$ \\ ${ }^{1}$ Department of Chemistry, Faculty of Science, United Arab Emirates University, Al-Ain, P.O. Box: 17551, U.A.E \\ ${ }^{2}$ Department of Forest Products and Engineering, College of Forestry, Oregon State University, Corvallis, Oregon 97330, U.S.A
}

\begin{abstract}
Two monoterpenes and two sesquiterpene diols were isolated and identified for the first time from the methanol extract of the heartwood of Alaska yellow cedar (AYC) tree. The two monoterpenes were identified as (1S)-2-oxo-3-p-menthenol (1) and (4R)-4-hydroxy-4-isopropylcyclohex-1-enecarboxylic acid (2). The two sesquiterpenes were identified as (5S, 7R, 10R, 11R)-eudesm-4(14)-ene-11, 12-diol (kudtdiol, 3) and (4R, 5S, 7R)-1(10)-eremophilene11,12-diol (tedonodiol, 4). Structures for these compounds were confirmed on the basis of spectroscopic data and in comparison with related known compounds. In addition, 10 other previously known AYC constituents were also isolated from the methanol extract of the heartwood of AYC including nootkatin, chamic acid, chaminic acid, carvacrol, methyl carvacrol, chanootin, nootkatene, nootkatone, valencene and valencene-13-ol.
\end{abstract}

Keywords Alaska Yellow Cedar, Natural Products, Tedonodiol, Kudtdiol

\section{Introduction}

Alaska yellow cedar (Chamaecyparis nootkatensis (D. Don) spach), also known as yellow cedar, Alaska cedar, yellow cypress, is a medium-sized tree that is up to 25 meters tall and $90 \mathrm{~cm}$ in diameter. It is one of the eleven genera that make the Cupressaceae (Cypress) family. The genus Chamaecyparis includes, in addition to Chamaecyparis nootkatensis, other common species such as Chamaecyparis obtusa (Japanese cypress), Chamaecyparis lawsoniana (Port-Orford cedar), Chamaecyparis formosensis, Chamaecyparis thyoides (Atlantic white cedar), Chamaecyparis taiwanensis, etc.

Several compounds have been isolated and identified from the heartwood extract of AYC including two tropolone sesquiterpenoids- nootkatin[1,2] and chanootin[3]; four monoterpenoids- chamic acid, chaminic acid, carvacrol, methyl carvacrol[4,5]; and four eremophilane-type sesquiterpenoids- nootkatene, nootkatone, valencene[6,7] and valencene-13-ol[8]. This paper describes the isolation and characterization of two monoterpenoids $(\mathbf{1}, \mathbf{2})$ and sesquiterpenoids $(3,4)$ from the methanolic extract of $\mathrm{AYC}$ heartwood (Table 1).

\section{Results and Discussion}

*Corresponding author:

mohammad.khasawneh@uaeu.ac.ae (M. A. Khasawneh)

Published online at http://journal.sapub.org/ajoc

Copyright (C) 2011 Scientific \& Academic Publishing. All Rights Reserved

\section{1. (-)-(1S)-2-Oxo-3-P-Menthenol, (1)}

This compound was isolated as yellow oil; $[\alpha]_{\mathrm{D}}{ }^{20}-85^{\circ}(\mathrm{c}$ $0.455, \mathrm{CHCl}_{3}$ ); IR (thin film) $v_{\max } 3450,1715,1620 \mathrm{~cm}^{-1}$; EIMS m/z $[\mathrm{M}]^{+} 168,153,151,125 ;$ HRCIMS m/z $[\mathrm{M}]^{+}$ 168.1143, calculated for $\mathrm{C}_{10} \mathrm{H}_{16} \mathrm{O}_{2}$, requires 168.1150. NMR spectral data are in Table 1. IR spectrum of $\mathbf{1}$ showed a strong absorption band at $1717 \mathrm{~cm}^{-1}$ and $3450 \mathrm{~cm}^{-1}$ characteristic of carbonyl and hydroxyl groups, respectively. The presence of two closely similar methyl groups that exhibit doublet signals suggests that there is an isopropyl group in this compound. The third methyl group being a singlet and shifted downfield suggests that it is attached to the ring where a hydroxyl group is also attached. The carbon atom NMR signal at $172.8 \mathrm{ppm}$ is generally of higher value than expected for alkenes, but a closer look at the literature reveals that high values like what we have here are observed for $\alpha, \beta$-unsaturated carbonyl compounds.

Further support for this conclusion comes from the ${ }^{13} \mathrm{C}-\mathrm{NMR}$ signal at 203ppm for the carbonyl carbon. Further details of structure 1 were verified by 2-D NMR spectra including HMBC and COSY (Table 1). These results reveal that the structure follows the menthane-type skeleton pattern frequently observed in plant species. Thedownfield -shifted methyl group (at $\delta_{\mathrm{H}} 1.33$ ) is located at $\mathrm{C}-1$ as evidenced by the HMBC correlations of its protons with C-2, C-6 and C-1 (203.3, 36.1 and 73.1ppm, respectively). The absence of correlations between the vinylic proton and the carbonyl carbon from one side and that between proton at $\delta_{\mathrm{H}} 2.48$ with the same carbon support the earlier conclusion that the isopropyl group is located at the $\beta$-carbon. Key COSY correlations of H-5 with H-6 and H-8 with H-9 and 
H-10 add further support for structure 1.

The absolute stereochemistry around $\mathrm{C}-1$ of this compound is extremely difficult to establish because it is a tertiary alcohol. However, $\mathbf{1}$ is related to a compound previously described in the literature as a product of the microbial fermentation of $\alpha$-terpinene. Compound 1 gave essentially identical ${ }^{1} \mathrm{H}$ and ${ }^{13} \mathrm{C} \mathrm{NMR}$ data as one of these products, which is (+)-(1R)-2-oxo-3-p-menthenol). However, optical rotation data obtained for $\mathbf{1}$ suggest that it is the enantiomer of the compound described in the literature (1 gave $[\alpha]_{D}-85^{\circ}\left(\mathrm{c} 0.455, \mathrm{CHCl}_{3}\right)$, while the literature compound gave $[\alpha]_{\mathrm{D}}+92.9$ (c $1.00, \mathrm{CHCl}_{3},[9]$. Based on this notion, the absolute configuration around $\mathrm{C}-1$ in compound $\mathbf{1}$ was indirectly deduced to be "S". Compound $\mathbf{1}$ was also reported by [10] as a chemical oxidation product of $\alpha$-terpinene. However, only IR data were reported in this reference.

\section{2. (+)-(4R)-4-Hydroxy-4-Isopropyl-Cyclohex-1- Ene- carboxylic Acid, 2}

This compound was isolated as white amorphous solid; $[\alpha]_{\mathrm{D}}{ }^{20}+25.5$ (c $0.275, \mathrm{CHCl}_{3}$ ); IR (thin film) $v_{\max }$ 2500-3500, 1620 $\mathrm{cm}^{-1}$; EIMS m/z 184 [M ], 167 [184-OH], $166\left[\mathrm{M}^{+}-\mathrm{H}_{2} \mathrm{O}\right], 151$ [166-Me], $141\left[\left[\mathrm{M}^{+}-\mathrm{CH}_{3} \mathrm{CHCH}_{3}\right], 138\right.$ [166-CO], 123 [138-Me]; HRCIMS [M] 184.1088 calculated for $\mathrm{C}_{10} \mathrm{H}_{16} \mathrm{O}_{3}$, requires 184.10995. NMR spectral data are in Table 2. From the molecular formula of $\mathrm{C}_{10} \mathrm{H}_{16} \mathrm{O}_{3}$ it follows that there are three degrees of un-saturation in this compound and from NMR data (both ${ }^{1} \mathrm{H}$ and ${ }^{13} \mathrm{C}$ ), there is only one C-C double bond. IR spectrum showed a strong absorption band at $2500-3500 \mathrm{~cm}^{-1}$ characteristic of a car- boxylic acid, which accounts for another degree of un-saturation. Therefore, there must be a ring in the structure of this molecule. The presence of two closely similar methyl groups in the ${ }^{1} \mathrm{H}$ NMR spectrum that exhibit doublet signals suggests that there is an isopropyl group. This conclusion is supported by the presence of a single proton that has a quartet signal correlated with two methyl groups in the COSY (Table 2). Therefore, it can be deduced that the ring is six-membered ring based on simple atom counts. The proton signal at $7.07 \mathrm{ppm}$ is generally of higher value than expected for vinylic protons, but a closer look at literature reveals that high values like what we have here are observed for $\beta$ - protons when there is an electron withdrawing group such as the carboxyl group attached at the $\alpha$-position of the alkene. Finally, the isopropyl group is deduced to be connected to the ring through $\mathrm{C}-4$ based on HMBC correlations of this carbon with $\mathrm{H}-8, \mathrm{H}-9$ and $\mathrm{H}-7$ protons. Other key $\mathrm{HMBC}$ correlations include those of $\mathrm{H}-2$ with C-10 and C-4, H-3 with C-2, H-5 with C-4 and C-6 (Table 2).

The specific rotation $\left([\alpha]_{\mathrm{D}}{ }^{20}\right)$ value for compound 2 was measured to be +25.5 (c $0.275, \mathrm{CHCl}_{3}$ ). The absolute stereochemistry was indirectly deduced based on comparison of this compound with another compound reported in the literature as a microbial fermentation product of (-)- $\beta$-pinene by Soil Pseudomonad (PL-Strain) [11]. Compound 2 produced an identical ${ }^{1} \mathrm{H}$ NMR spectrum to literature compound. However, these two compounds have opposite optical rotation signs and therefore compound $\mathbf{2}$ was assigned the "R" stereochemistry at C-4.

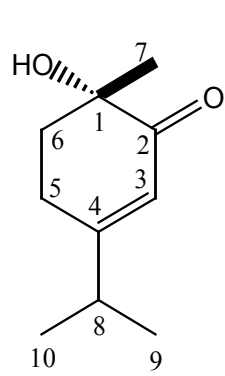

1<smiles>CC(C)C1(O)CCC(C(=O)O)CC1</smiles>

2

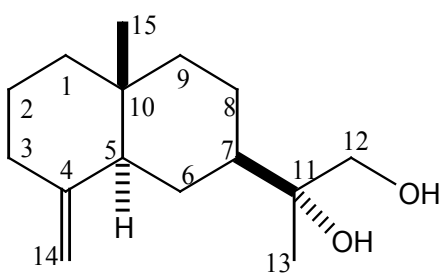

3

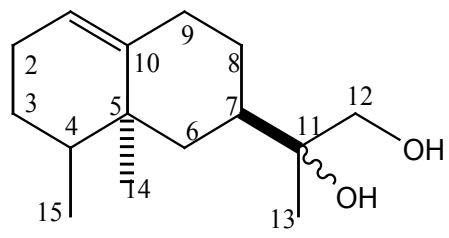

4

Table 1. NMR data for compound $\mathbf{1}$ in $\mathrm{CDCl}_{3}\left(400 \mathrm{MHz}\right.$ for ${ }^{1} \mathrm{H}$ and $100 \mathrm{MHz}$ for $\left.{ }^{13} \mathrm{C}\right)$

\begin{tabular}{|c|c|c|c|c|}
\hline Position & ${ }^{1} \mathrm{H}$ (Integration, ${ }^{\mathrm{a}}$ multiplicity, $\mathrm{J}$ in $\mathrm{Hz}$ ) & ${ }^{13} \mathrm{C}$ (type) ${ }^{\mathrm{b}}$ & $\mathrm{HMBC}^{\mathrm{c}}$ & $\operatorname{COSY}^{\mathrm{d}}$ \\
\hline 1 & e & $73.1(\mathrm{C})$ & - & - \\
\hline 2 & - & $203.3(\mathrm{C})$ & - & 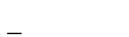 \\
\hline 3 & $5.93(1 \mathrm{H}, \mathrm{q}, \mathrm{J}=1.3)$ & $120.5(\mathrm{CH})$ & C-5, C-8, C-1 & _ \\
\hline 4 & 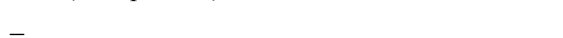 & $172.8(\mathrm{C})$ & - & - \\
\hline 5 & $\overline{2} .46(2 \mathrm{H}, \mathrm{m})$ & $27.3\left(\mathrm{CH}_{2}\right)$ & $\overline{\mathrm{C}}-8, \mathrm{C}-6, \mathrm{C}-1, \mathrm{C}-3, \mathrm{C}-4$ & $\overline{\mathrm{H}}-6(\alpha, \beta)$ \\
\hline 6 & $\begin{array}{l}2.16(1 \mathrm{H}, \mathrm{dt}, \mathrm{J}=12.9,3.02) ; 1.98-2.05(1 \mathrm{H}, \mathrm{ddd}, \\
\mathrm{J}=12.0,8.0,8.0)\end{array}$ & $36.1\left(\mathrm{CH}_{2}\right)$ & $\mathrm{C}-2, \mathrm{C}-7, \mathrm{C}-1, \mathrm{C}-4$ & $\mathrm{H}-5(\alpha, \beta)$ \\
\hline 7 & $1.33(3 \mathrm{H}, \mathrm{s})$ & $24.6\left(\mathrm{CH}_{3}\right)$ & $\mathrm{C}-2, \mathrm{C}-6, \mathrm{C}-1$ & - \\
\hline 8 & $2.48(1 \mathrm{H}, \mathrm{m})$ & $36.0(\mathrm{CH})$ & $\mathrm{C}-9, \mathrm{C}-10, \mathrm{C}-3, \mathrm{C}-4$ & H-9, H-10 \\
\hline $9^{c}$ & $1.16(3 \mathrm{H}, \mathrm{d}, \mathrm{J}=6.8)$ & $21.1\left(\mathrm{CH}_{3}\right)$ & C-10, C-8, C-4 & $\mathrm{H}-8$ \\
\hline $10^{\mathrm{c}}$ & $1.14(3 \mathrm{H}, \mathrm{d}, \mathrm{J}=6.8)$ & $21.4\left(\mathrm{CH}_{3}\right)$ & C-9, C-8, C-4 & $\mathrm{H}-8$ \\
\hline
\end{tabular}

${ }^{\mathrm{a}} \mathrm{m}=$ multiplet, $\mathrm{d}=$ doublet, $\mathrm{q}=$ quartet, $\mathrm{s}=$ singlet, $\mathrm{br}=$ broad. ${ }^{\mathrm{b}}$ Results obtained from DEPT 90 and 135 spectra. ${ }^{\mathrm{c}}$ Proton showing long-range ( mainly 2 and 3 bond) correlation to indicated carbon(s). ${ }^{\mathrm{d}}$ Protons showing (vicinal) correlations to the indicated proton(s). 
Table 2. NMR data for compound 2 in $\mathrm{CDCl}_{3}\left(400 \mathrm{MHz}\right.$ for ${ }^{1} \mathrm{H}$ and $100 \mathrm{MHz}$ for $\left.{ }^{13} \mathrm{C}\right)$

\begin{tabular}{|c|c|c|c|c|}
\hline Position & ${ }^{1} \mathrm{H}$ (Integration, multiplicity ${ }^{\mathrm{a}}, \mathrm{J}$ in $\mathrm{Hz}$ ) & ${ }^{13} \mathrm{C}$ (type) ${ }^{\mathrm{b}}$ & $\begin{array}{l}\text { HMBC correlations of } \\
\text { Hydrogen }^{c}\end{array}$ & $\begin{array}{l}\text { COSY correlations of } \\
\text { Hydrogen }^{\mathrm{d}}\end{array}$ \\
\hline 1 & & $129.6(\mathrm{C})$ & - & - \\
\hline 2 & $\overline{7} .07(1 \mathrm{H}, \mathrm{m})$ & $140.2(\mathrm{CH})$ & $\mathrm{C}-4, \mathrm{C}-10$ & $\mathrm{H}-3(\alpha, \beta)$ \\
\hline 3 & $2.37(1 \mathrm{H}, \mathrm{dd}, \mathrm{J}=7.0,3.1$, equatorial $), 2.25(1 \mathrm{H}, \mathrm{m}$, axial $)$ & $35.5\left(\mathrm{CH}_{2}\right)$ & $\mathrm{C}-1, \mathrm{C}-2$ & $\mathrm{H}-2$ \\
\hline 4 & & $72.1(\mathrm{C})$ & - & - \\
\hline 5 & $\begin{array}{l}1.81(1 \mathrm{H}, \mathrm{dddd}, \mathrm{J}=13.6,5.7,3.3,2.1) ; 1.59(1 \mathrm{H}, \mathrm{ddd}, \\
\mathrm{J}=8.4,4.3,3.8)\end{array}$ & $30.8\left(\mathrm{CH}_{2}\right)$ & $\mathrm{C}-6, \mathrm{C}-4$ & $\mathrm{H}-6(\alpha, \beta)$ \\
\hline 6 & $2.45(1 \mathrm{H}, \mathrm{m}) ; 2.42(1 \mathrm{H}, \mathrm{m})$ & $21.3\left(\mathrm{CH}_{2}\right)$ & $\mathrm{C}-5, \mathrm{C}-1$ & H-5 $(\alpha, \beta)$ \\
\hline 7 & $1.72(1 \mathrm{H}, \mathrm{q}, \mathrm{J}=6.86)$ & $37.8(\mathrm{CH})$ & $\mathrm{C}-4, \mathrm{C}-8, \mathrm{C}-9$ & H-8, H-9 \\
\hline $8 *$ & $1.01(3 \mathrm{H}, \mathrm{d}, \mathrm{J}=6.86)^{*}$ & $17.1 *\left(\mathrm{CH}_{3}\right)$ & $\mathrm{C}-7$ & $\mathrm{H}-7$ \\
\hline $9^{*}$ & $0.99(3 \mathrm{H}, \mathrm{d}, \mathrm{J}=6.86)^{*}$ & $17.2 *\left(\mathrm{CH}_{3}\right)$ & $\mathrm{C}-7$ & $\mathrm{H}-7$ \\
\hline 10 & - & $172.1(\mathrm{C})$ & - & - \\
\hline
\end{tabular}

${ }^{\mathrm{a}} \mathrm{s}=$ singlet, $\mathrm{d}=$ doublet, $\mathrm{t}=$ triplet, $\mathrm{q}=$ quartet, $\mathrm{m}=$ multiplet, $\mathrm{b}=$ broad. ${ }^{\mathrm{b}}$ results obtained from DEPT 90 and 135 spectra. Assignments are based on the results of HSQC experiments. ${ }^{c}$ Proton showing one-bond correlation to the indicated carbon. ${ }^{d}$ Protons showing (vicinal) correlations to the indicated proton(s). * Assignment may be interchangeable.

Table 3. NMR data for compound 4 in $\mathrm{CDCl}_{3}\left(400 \mathrm{MHz}\right.$ for ${ }^{1} \mathrm{H}$ and $100 \mathrm{MHz}$ for $\left.{ }^{13} \mathrm{C}\right)$

\begin{tabular}{|c|c|c|c|c|}
\hline Position & ${ }^{1} \mathrm{H}$ (Integration, multiplicity ${ }^{\mathrm{a}}, \mathrm{J}$ in $\mathrm{Hz}$ ) & ${ }^{13} \mathrm{C}\left(\right.$ type $\left.^{\mathrm{b}}\right)$ & $\mathrm{HMBC}^{\mathrm{c}}$ & $\operatorname{COSY}^{\mathrm{d}}$ \\
\hline 1 & $5.36(1 \mathrm{H}, \mathrm{m})$ & $120.6(\mathrm{CH})$ & $38.0,32.9,27.6,26.3$ & $\mathrm{H}-2$ \\
\hline 2 & $1.98(2 \mathrm{H}, \mathrm{m})$ & $26.3\left(\mathrm{CH}_{2}\right)$ & NR & $\begin{array}{l}\mathrm{H}-3, \quad \mathrm{H}-4, \\
\mathrm{H}-2^{\prime}\end{array}$ \\
\hline 3 & $1.46(2 \mathrm{H}, \mathrm{m})$ & $27.6\left(\mathrm{CH}_{2}\right)$ & $\begin{array}{l}120.6,41.5,16.1,38.0 \\
143.4\end{array}$ & H-4, H-3' \\
\hline 4 & $1.46(1 \mathrm{H}, \mathrm{m})$ & $41.5(\mathrm{CH})$ & $27.6,16.1,38.0$ & $\mathrm{H}-15, \mathrm{H}-3$ \\
\hline 5 & & $38.0(\mathrm{C})$ & - & \\
\hline 6 & $2.02(1 \mathrm{H}, \mathrm{ddd}, \mathrm{J}=12.6,3.4,2.5) ; 0.92(1 \mathrm{H}, \mathrm{m})$ & $39.9\left(\mathrm{CH}_{2}\right)$ & $\bar{N} R$ & $(\mathrm{H}-7, \mathrm{H}-8)^{\mathrm{f}}$ \\
\hline 7 & $1.87(1 \mathrm{H}$, apparent $\mathrm{tt}, \mathrm{J}=12.6,3.02)$ & $40.4(\mathrm{CH})$ & $69.0,75.1$ & $H-8,(H-6)^{f}$ \\
\hline 8 & $\begin{array}{l}1.74(1 \mathrm{H}, \mathrm{dddd}, \mathrm{J}=12.2,4.7,2.6,1.8) ; 1.03(1 \mathrm{H}, \mathrm{dd}, \mathrm{J}=12.6 \text {, } \\
4.01)\end{array}$ & $29.6\left(\mathrm{CH}_{2}\right)$ & 32.9 & $\mathrm{H}-9, \mathrm{H}-8^{\prime}$ \\
\hline 9 & $2.31(1 \mathrm{H}, \mathrm{mt}, \mathrm{J}=13.5) ; 2.10(1 \mathrm{H}, \mathrm{ddd}, \mathrm{J}=14.3,5.52,2.83)$ & $32.9\left(\mathrm{CH}_{2}\right)$ & $120.6,143.4$ & H-8, H-9' \\
\hline 10 & - & $143.4(\mathrm{C})$ & - & - \\
\hline 11 & - & $75.1(\mathrm{C})$ & - & - \\
\hline 12 & $3.62(1 \mathrm{H}, \mathrm{bd}, \mathrm{J}=10.9) ; 3.46(1 \mathrm{H}, \mathrm{bd}, \mathrm{J}=10.9)$ & $69.0\left(\mathrm{CH}_{2}\right)$ & $20.9,75.1,40.4$ & $\bar{H}-12^{\prime}$ \\
\hline 13 & $1.11(3 \mathrm{H}, \mathrm{s})$ & $20.9\left(\mathrm{CH}_{3}\right)$ & $75.1,69.0,40.4$ & - \\
\hline 14 & $0.94(3 \mathrm{H}, \mathrm{s})$ & $18.8\left(\mathrm{CH}_{3}\right)$ & $143.4,38.0,39.9,41.5$ & - \\
\hline 15 & $0.90(3 \mathrm{H}, \mathrm{d}, \mathrm{J}=6.1)$ & $16.1\left(\mathrm{CH}_{3}\right)$ & $27.6,18.8,38.0,41.5$ & H-4 \\
\hline
\end{tabular}

${ }^{\mathrm{a}} \mathrm{s}=$ singlet, $\mathrm{d}=$ doublet, $\mathrm{t}=$ triplet, $\mathrm{q}=$ quartet, $\mathrm{m}=$ multiplet, $\mathrm{b}=$ broad. ${ }^{\mathrm{b}}$ results obtained from DEPT 90 and 135 spectra. ${ }^{\mathrm{d}}$ Proton showing long-range (mainly 2- and 3-bond) correlation to indicated carbon(s). ${ }^{\mathrm{e}}$ Protons showing (vicinal) correlations to the indicated proton(s). ${ }^{\mathrm{f}}$ not observable because the proton signals are not resolved from larger signals.

\section{3. (5S, 7R, 10R, 11R)-Eudesm-4(14)-Ene-11, 12-Diol (Kudntdiol), 3}

This compound was isolated as white amorphous solid; $[\alpha]_{\mathrm{D}}^{20}+66.8^{\circ}\left(\mathrm{c} 0.25, \mathrm{CHCl}_{3}\right)$; IR (thin film) $v_{\max } 3450 \mathrm{~cm}^{-1}$; EIMS m/z $[\mathrm{M}]^{+} 238\left(\mathrm{M}^{+}\right), 220\left(\mathrm{M}^{+}-\mathrm{H}_{2} \mathrm{O}\right), 207\left(\mathrm{M}^{+}-\mathrm{CH}_{2} \mathrm{OH}\right)$, $202\left(\mathrm{M}^{+}-2 \mathrm{H}_{2} \mathrm{O}\right)$ and $189\left(\mathrm{M}^{+}-\mathrm{CH}_{2} \mathrm{OH}-\mathrm{OH}\right) ; \mathrm{HRCIMS} \mathrm{m} / \mathrm{z}$ $[\mathrm{M}]^{+} 238.19377$, calculated for $\mathrm{C}_{15} \mathrm{H}_{26} \mathrm{O}_{2}$, requires 238.1933 . ${ }^{1} \mathrm{H}$ NMR spectral data were in good agreement with literature data for kudntdiol[12] and therefore are not listed here. The value of the optical rotation for kudtdiol isolated in this work from AYC $\left([\alpha]_{\mathrm{D}}+66.8^{\circ}\left(\mathrm{c} 0.25, \mathrm{CHCl}_{3}\right)\right)$ is in good agreement with the reported value for the same compound in the literature $\left([\alpha]_{\mathrm{D}}+72.9^{\circ}\left(\mathrm{CHCl}_{3}\right)\right)$. The absolute stereochemistry around the bicyclic ring chirality centers (C-5, $\mathrm{C}-7, \mathrm{C}-10$, and C-11) of $\mathbf{3}$ was established in reference [13].

Compound $\mathbf{3}$ belongs to a family of sesquiterpenes called the eudesmanes, which is a large group of sesquiterpenes widely occurring in the plant kingdom. It has been previously isolated from the aerial parts of Jasonia glutinosa and named as kudtdiol[13] and it has not been reported for any other species to date. Therefore, the isolation of kudtdiol (3) from AYC is a new and important finding. This is in fact the first report to indicate the presence of a eudesmane-type skeleton in AYC. This fact makes AYC a unique species in the Cupressaceae family since the eremohpilane-type sesquiterpenes are extremely rare in this family. Chamaecyparis lawsoniana (Port Orford Cedar) on the other hand, has been shown to have eudesmane-type skeleton as the dominant sesquiterpene content.

\section{4. (4R, 5S, 7R)-1(10)-Eremohpilen-11, 12-Diol, 4}

This compound was isolated as yellow oil; $[\alpha]_{D}{ }^{20}-17.3$ (c $0.66, \mathrm{CHCl}_{3}$ ); IR (thin film) $v_{\max } 3450,1620 \mathrm{~cm}^{-1} ;$ EIMS m/z $238 \quad\left(\mathrm{M}^{+}\right), \quad 220 \quad\left(\mathrm{M}^{+}-\mathrm{H}_{2} \mathrm{O}\right), \quad 207 \quad\left(\mathrm{M}^{+}-\mathrm{CH}_{2} \mathrm{OH}\right), \quad 202$ $\left(\mathrm{M}^{+}-2 \mathrm{H}_{2} \mathrm{O}\right), 189\left(\mathrm{M}^{+}-\left(\mathrm{CH}_{2} \mathrm{OH}+\mathrm{OH}\right), 161\left(189-\mathrm{CHCH}_{3}\right.\right.$, the decaline system residue); HRCIMS m/z [M] ${ }^{+} 238.1938$, calculated for $\mathrm{C}_{15} \mathrm{H}_{26} \mathrm{O}_{2}$, requires 238.1933). NMR spectral data are included in Table 3. These data were in agreement with those reported by (Guerreiro et al 1979). The molecu- 
lar formula was determined on the basis of HRCIMS ion peak at 238.1938 to be $\mathrm{C}_{15} \mathrm{H}_{26} \mathrm{O}_{2}$ (required for $\mathrm{C}_{15} \mathrm{H}_{26} \mathrm{O}_{2}$ is 238.1933). EIMS showed peaks at $238\left(\mathrm{M}^{+}\right), 220\left(\mathrm{M}^{+}-\mathrm{H}_{2} \mathrm{O}\right)$, $207\left(\mathrm{M}^{+}-\mathrm{CH}_{2} \mathrm{OH}\right), 202\left(\mathrm{M}^{+}-2 \mathrm{H}_{2} \mathrm{O}\right), 189\left(\mathrm{M}^{+}-\left(\mathrm{CH}_{2} \mathrm{OH}+\mathrm{OH}\right)\right.$, $161\left(189-\mathrm{CHCH}_{3}\right.$, the decaline system residue) as the main fragment peaks. IR spectroscopy indicated the presence of an alcoholic functional group in the molecule.

All the above results suggest that the structure of this compound maybe related to that of $\mathbf{3}$ described above. However, a closer look at the 2-D NMR (HMBC and CO$\mathrm{SY})$, reveals that the structure of 4 exhibits the eremophilane skeleton, which is widely found in the heartwood of AYC. Among the key correlations observed in the HMBC spectrum, which played a major role in the assignment of the structure of this compound are the $\mathrm{H}-14$ correlations with C-10, C-4 and C-6. These correlations show that this methyl is attached to $\mathrm{C}-5$. Other important correlations are those of $\mathrm{H}-15$ with $\mathrm{C}-14, \mathrm{C}-3, \mathrm{C}-4$ and $\mathrm{C}-5$, which suggests that the $\mathrm{C}-15$ methyl is attached to $\mathrm{C}-4$ and that $\mathrm{C}-15$ and $\mathrm{C}-14$ methyls are vicinal to each other. Correlations of $\mathrm{H}-12$ and $\mathrm{H}-13$ with $\mathrm{C}-7$ on one hand and those of $\mathrm{H}-7$ with $\mathrm{C}-11$, $\mathrm{C}-12$ and $\mathrm{C}-13$ on the other hand demonstrate that the attachment between the bicyclic ring and the side chain occurs as expected, through C-7. HMBC correlations of $\mathrm{H}-12$ with $\mathrm{C}-11$ and $\mathrm{C}-13$ and correlations of $\mathrm{H}-13$ with $\mathrm{C}-11$ and $\mathrm{C}-12$ suggest that the side chain diol has the arrangement shown in the structure. COSY spectrum correlations provide a support for these conclusions.

Compound $\mathbf{4}$ was previously isolated as a natural product from the plant Tessaria dodonelfolia and named as tedonodiol[14]. The structure was assigned mainly based on chemical transformations as well as ${ }^{1} \mathrm{H}$ NMR data, of which only the most important part was described while no ${ }^{13} \mathrm{C}$-NMR data were reported. A comparison of the data reported in the present work and those in the reference reveals that there is good agreement in the ${ }^{1} \mathrm{H}$ NMR data except that there is a systematic shift of about positive $0.07-0.10 \delta_{\mathrm{H}}$ units in the data reported here for most of the signals.

The value of the optical rotation was measured to be $[\alpha]_{589}-17.3$ (c $\left.0.66, \mathrm{CHCl}_{3}\right)[14]$. To shed some light on the conformational arrangement of the bicyclic system of 4 , the nuclear overhauser effect (NOE) should be useful. In the NOESY spectrum measured in this study, the correlation between $\mathrm{H}-7$ and $\mathrm{H}-14$ suggests that these two types of protons occur in spatial proximity (Figure 1). The correlation of $\mathrm{H}-14$ with $\mathrm{H}-15$, which is more difficult but can be observed, suggests that $\mathbf{4}$ has the usual conformation of eremophilanes isolated previously from AYC.

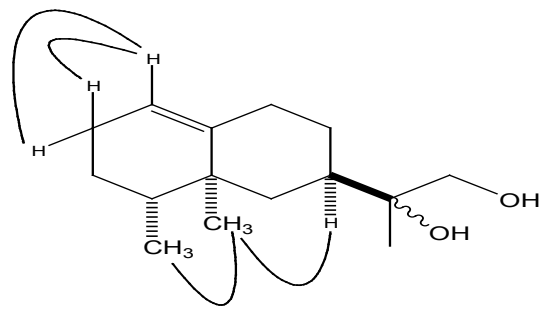

Figure 1. NOE correlations observed for 4 .
In summary, the $\mathrm{AYC}$ heartwood was found to contain many constituents that have never been described before in AYC. In the monoterpene group, two compounds were isolated and identified (compounds $\mathbf{1}$ and 2) in this research. These two compounds add to the previously known series of monoterpenes in this tree. The compounds share together a general skeleton, which is the menthane- type skeleton widely encountered in plants. In the sesquiterpene family, two compounds were isolated 3 and 4 . One of the compounds has an eremophilane skeleton type common to AYC heartwood. The other compound follows the eudesmane skeleton type, which is the first eudesmane-type compound to be isolated from AYC.

\section{Materials and Methods}

\subsection{Materials}

Hexane (EM Science, Gibbstown, NJ, glass distilled 99.4\%) was used as received. Acetone (99.6\%), Ethyl Acetate $(99.9 \%)$, Dichloromethane $(99.9 \%)$ and Methanol (99.9\%) were all purchased from Fisher Scientific, Fair Loan, NJ and distilled prior to use. Diethyl ether (EM Science, Gibbstown, NJ 98\%) was used as received. Chloroform (Mallinckrodt Baker Inc., Paris, KY, 99.9\%) was used as received. Deuterated chloroform (Aldrich Chemical company, Milwaukee, WI, 99.9 atom \%D) was used as received for NMR experiments. Anhydrous $\mathrm{Na}_{2} \mathrm{SO}_{4}$ (Fisher Scientific, Fair Lawn, NJ, 100\%), Silica gel (EM Science, particle size $0.063-0.200 \mathrm{~mm}, 70-230$ mesh ASTM), TLC plates (EM Science, Kieselgel $60 \mathrm{~F}_{254}$ coated on Aluminum support) were all used as received.

\subsection{Plant Extraction}

AYC tree was collected from the Hungry Mountain area on the Sol Duc River Drainage on the western slopes of the Olympic Mountains in the Olympic National Forest, WA, USA. A collection permit was obtained from the Sol Duc ranger station in Forks, WA. A botanical voucher specimen (\#188046) is deposited in the Oregon State University Herbarium. Heartwood was separated from the rest of the components and chipped in a grinder to a size of approximately $2 \mathrm{X} 1 \mathrm{~cm}$ chips and kept at room temperature in the dark until used. The chipped AYC heartwood sample $(1000 \mathrm{~g})$ was soaked in methanol $(2.5 \mathrm{~L})$ in a $5.0 \mathrm{~L}$ conical flask with continuous stirring for $24 \mathrm{~h}$. The mixture was gravity filtered through a $15 \mathrm{~cm}$ filter paper. Anhydrous $\mathrm{Na}_{2} \mathrm{SO}_{4}$ was added to the filtrate and the mixture was re-filtered. The filtrate was concentrated in vacuum to give thick dark brown oil $(43 \mathrm{~g}, 4.3 \%$ based on the wet wood mass).

\subsection{Chromatographic Separation of Constituents}

A 1-g sample of the methanol extract was chromatographed on a silica gel column using a gradient elution system of increasing polarity from 100:0 to 50:50 Hex:EtOAc 
$(\mathrm{v} / \mathrm{v})$ resulting in nine main fractions I -VII: fraction I (mainly valencene and nootkatene as checked by TLC and GC against standards), fraction II (mainly carvacrol by TLC and GC), fraction III (mainly nootkatol and nootkatone). Fraction IV was carefully chromatographed over a silica gel column with Hex-EtOAc (80:20) to provide compound 1 $\left(12 \mathrm{mg}, \mathrm{R}_{\mathrm{f}}=0.56\right.$, Hex-EtOAc (50:50)) as a colorless oily residue and compound $3\left(11 \mathrm{mg}, \mathrm{R}_{\mathrm{f}}=0.46\right.$, Hex:EtOAc $(50: 50))$ as a colorless amorphous solid. Fraction $\mathrm{V}$ was mainly composed of compound $4\left(43 \mathrm{mg}, \mathrm{R}_{\mathrm{f}}=0.36 \quad 50: 50\right.$ Hex:EA) as yellow oil with fair purity $(>90 \%)$ by NMR. Fraction VI contained mainly chamic acid $(13 \mathrm{mg})$ and chaminic acid $(8 \mathrm{mg}$ ) both with good purity (checked by TLC and GC). This fraction was not investigated any further since these two compounds have been described before. Fraction VII contains mainly compound $2\left(7 \mathrm{mg}, \mathrm{R}_{\mathrm{f}}=0.24\right.$ in Hex-EtOAc (50:50)) with purity of more than $95 \%$ shown by NMR. NMR measurements were recorded on a Bruker Avance NMR $\left(400 \mathrm{MHz}\right.$ in the case of ${ }^{1} \mathrm{H}$ and $100 \mathrm{MHz}$ in the case of ${ }^{13} \mathrm{C}$ ) spectroscopy instrument using $\mathrm{CDCl}_{3}$ as a solvent.

\section{REFERENCES}

[1] Aulin G., Erdtman H., 1950, Studies of the tropolone series. I: Thujaplicins and nootkatin. Acta Chem. Scand. 4, 1031-1041

[2] Duff S.R., Erdtman H., 1954, The chemistry of the natural order of Cupressales. X: Nootkatin. Chem. Industry 15, $432-433$

[3] Carlsson B., Pillot A. M., Wiehager A. C., 1973, The crystal structure of chanootin, a bi-cyclic 15 carbon tropolone. Acta Cryst. B29, 1209-1213

[4] Carlsson B., Erdtman H., Frank, A. A., Harvey, W. E., 1952, The chemistry of the natural order Cupressales. VIII: Heartwood constituents of Chamaecyparis nootkatensis--carvacrol, nootkatin and chamic acid. Acta Chem. Scand. 6, 690-696
[5] Norin T., 1964, The chemistry of the natural order Cupressales. Part 50: The absolute configurations of chamic, chaminic, and isochamic acids. Arkiv. For. Femi, Stockholm 22, $123-128$

[6] Erdtman H., Topliss J. G., 1957, The chemistry of the natural order Cupressales. XVIII: Nootkatene, a new sesquiterpene type hydrocarbon from the heartwood of Chamaecyparis nootkatensis (Lamb.) Acta Chem. Scand., 11, 1157-1161

[7] Erdtman H., Hirose Y., 1962, The chemistry of the natural order Cupressales. 46: The structure of nootkatone. Acta Chem. Scand. 16, 1311-1314

[8] Mohammad A. Khasawneh, Yeping Xiong, Javier Peralta-Cruz and Joe J. Karchesy, 2011, Biologically Important Eremophilane Sesquiterpenes from Alaska Cedar Heartwood Essential Oil and Their Semi-Synthetic Derivatives. Molecules, 16, 4775-4785

[9] Abraham W. R., Stumpf B., Kieslich K., 1986, Microbial transformations of terpenoids with 1-p-menthene skeleton. Appl Microbiol Biotechnol, 24, 24-30

[10] Takayuki S., Tsuyoshi S., Tamon, M., 1968, Stereochemical studies of monoterpene compounds. III. stereochemistry and intramolecular hydrogen bonding of 1-hydroxy-p-menth-3en-2one and its reduction products. Bull. Chem. Soc. Jpn. 41, 944-948

[11] Shukla O. P., Moholay M. N., Bhattacharyya, P. K., 1986, Microbiological Transformations of Terpenes: Part X- Fermentation of $\alpha$ - and $\beta$-Pinenes by a Soil Pseudomonad (PL-Strain). Ind J Biochem, 5, 79-91

[12] Rodrigues V. F., Carmo H. M., Oliveira R. R., Filho R. B., Mathias L., Vieira I. J., 2009, Isolation of Terpenoids from Trichilia quadrijuga (Meliaceae) by Droplet Counter-Current Chromatography, 70, 1191-1195

[13] Teresa J. P., Barrero A. F., San Feliciano A., Grande M., Medrade., 1978, Kudtdiol, new sesquiterpene alcohol from Jasonia glutinosa D.C. Tetrahedron Lett. 19, 4141-4144

[14] Guerreiro E., Kavka J., Giordano O. S., 1979, Tedonodiol, an Eremophilano Derivative from Tessaria Dodoneifolia (Hook. et Arn.) Cabr. Anals Asoc. Quim. Argent, 67, 119-123 